Article

\title{
The Influence of Local Governance: Effects on the Sustainability of Bioenergy Innovation
}

\author{
Bianca Cavicchi ${ }^{1, *}$, Sergio Palmieri ${ }^{2,3}$ and Marco Odaldi ${ }^{2,3}$ \\ 1 Norwegian Institute of Bioeconomy Research (NIBIO), 0155 Oslo, Norway \\ 2 Ex Centro Innovazione Sostenibilità Ambientale (CISA), 40046 Bologna, Italy; palmieri@centrocisa.it (S.P.); \\ modaldi@aess-modena.it (M.O.) \\ 3 now Agenzia per l'energia e lo Sviluppo Sostenibile (AESS), 41122 Modena, Italy \\ * Correspondence: bianca.cavicchi@nibio.no
}

Academic Editors: Antje Klitkou and Teis Hansen

Received: 28 November 2016; Accepted: 21 February 2017; Published: 9 March 2017

\begin{abstract}
This paper deals with processes and outcomes of sustainable bioenergy development in Emilia Romagna. It draws on an on-going research project concerning inclusive innovation in forest-based bioenergy and biogas in Norway, Sweden, Finland and Italy. The goal is to explore how local governance impacts on inclusive innovation processes and triple bottom sustainability of bioenergy development in Emilia Romagna and, ultimately, to contribute to the debate on the bioeconomy. It thus compares the case of biogas and forest-based bioenergy production. The study adopts an analytical framework called Grounded Innovation (GRIP) and the local governance approach. The study uses qualitative methods and particularly semi-structured interviews and governance analysis. The key results show different outcomes on both inclusive innovation and triple bottom-line dimensions. Biogas has not fostered inclusiveness and triple bottom line sustainability benefits, contrary to forest-based bioenergy. The findings indicate that the minor role of local actors, particularly municipalities, in favour of industrial and national interests may jeopardise the sustainability of biobased industries. Besides, policies limited to financial incentives may lead to a land-acquisition rush, unforeseen local environmental effects and exacerbate conflicts.
\end{abstract}

Keywords: bioenergy; sustainability; grounded innovation; rural development; local governance

\section{Introduction}

The paper draws on the evidence gathered during the research work of the TRIBORN project (the project that financed this study) and other relevant studies (e.g., [1]). These studies prove that, although bioenergy is expected to benefit rural societies and economies, it has in many cases generated harmful consequences, such as a rush to land acquisition, particularly by means of external entrepreneurs and multinationals; social conflicts, soil quality degradation and unexpected costs (e.g., [1-8]). However, the most successful cases indicate that one factor can markedly mitigate or even avoid these harmful effects, namely the proactive role of municipalities and the creation of partnerships among local actors. Thus, an interesting case would be to explore the cases where local authorities and partnerships are absent and compare them with the opposite scenario. The comparison could shed light on how the outcomes may differ in the two scenarios and the structural reasons behind the lack or presence of local partnerships and effective local governance.

This study will thus concentrate on Emilia Romagna, an Italian region that within the European context shows some of the most drastic consequences of bioenergy development mentioned above (e.g., social malcontent, local environmental issues and economic downturns for rural areas). The paper will explore the local governance and its capacity to foster sustainable outcomes of two types of bioenergy systems based on two different technologies and products (i.e., anaerobic digestion 
electricity and wood combustion heat). The two cases present opposite local governance scenarios and, thus, it will be interesting to compare them and see how the lack of local partnerships and effective local governance may hinder simultaneous Triple Bottom Line Sustainability (TBL) benefits of bioenergy development. On the one hand, the Triple Bottom Line [9] conveys a holistic perspective of sustainability which sees economic, social and environmental processes intertwine and mutually influence each other. The TBL approach debunks the predominant approach to sustainability with its principal focus on the environmental dimension and environmental outcomes often seen as mere externalities of economic activities rather than part of feedback processes between the environment and the social world. In other words, we could consider bioenergy production as an economic activity that has an impact on the surrounding natural and anthropic environment (e.g., soil, water, air, and landscape), thus stimulating the reaction of the communities who live nearby. Whether this response is positive or negative, it will certainly affect the next political, business, financial and environmental decisions that will carry on the transition process at different levels. On the other hand, looking at the local governance structure can be very useful to delineate the way these decisions are taken and implemented (i.e., which actors, rules, and responsibilities). Thus, the policies, processes and outcomes it generates and, whether changes could be necessary.

The paper is structured as follows. It first frames bioenergy within the wider context of the bioeconomy by discussing the links and its relevance to understand some of the dynamics of the bioeconomy. Secondly, it delineates the theoretical framework seeking to link the Triple Bottom Line approach to governance and which methodology has been used to investigate the research questions. Thirdly, it presents the regional context and the case of biogas and forest-based bioenergy development within it. Finally, it discusses the results based on the theoretical framework and concludes with some recommendations on important governance innovations.

\section{Problem Articulation}

This study is framed within the wider bioeconomy framework and its underlying assumptions. According to the European Commission, "the bioeconomy comprises those parts of the economy that use renewable biological resources from land and sea-such as crops, forests, fish, animals and micro-organisms-to produce food, materials and energy" (https://ec.europa.eu/research/bioeconomy/index.cfm). Based on this definition, it can be said that the bioeconomy is both an old and new field. It relies on long-established sectors such as agriculture, forestry and fishery but also on more innovative industries, such as food industry, manufacturing, biochemicals and energy, among others. It is thus a complex domain, which can have impacts on climate change, social inclusion and eco-systems of rural and urban areas on, among other things, through dynamic and non-linear processes that span in space and time. This complexity requires a capacity of rural territories-where most of the natural resources and related industries are located-to adapt to the new and changing conditions, including the possibility to cooperate with new actors, domains and scales.

Bioenergy is indeed part of this bioeconomy framework (i.e., it uses land-related resources and relies on old and new sectors such as agriculture, forestry, manufacturing and biochemical) and thus provides a rather good case for the benefits and challenges that the development of the bioeconomy poses. One of the core challenges is, for instance, the need to integrate economic, social and environmental considerations, cross-level elements (e.g., policies, governance, and effects) and connect different industries. As mentioned, the paper draws on the work of an on-going research project (TRIBORN) on forms of grounded, inclusive innovation in forest-based bioenergy and biogas in Norway, Sweden, Finland and Italy [10-12]. TRIBORN is particularly concerned with processes and outcomes of bioenergy development at the local and regional level and adopts the triple bottom line perspective to produce knowledge on how innovation systems should be designed to promote sustainable bioenergy development. One of the main research findings in TRIBORN $[8,10-15]$ emphasises that local authorities have been, and will remain, crucial for the development of local bioenergy in Scandinavia. Municipalities are important as customers, regulators, planners and 
facilitators for business development both in short and in the long run-and they can empower citizens in stimulating new forms of local business models. Furthermore, regions and municipalities together can create strategies for sustainable development for their local areas indicating an overall pathway for entrepreneurs to take initiatives. Where municipalities and regional authorities have not taken these actions, as in the case of biogas production in Emilia Romagna, there seem to be major problems on the triple bottom line dimension $[2,8,12,13]$.

Therefore, this paper investigates the case of the Emilia Romagna region in Italy and puts particular attention on the local governance dimension. Emilia Romagna is a Northeastern Italian region which territory is split into two different biophysical areas: a flat, plain area called Po Valley or Padana Plain, and a mountainous area named Tosco-Emilian and Tosco-Romagnolo Apennines. The two territories have different economic, social and environmental features. On the one hand, the Po Valley is completely flat, has abundant farmland and specialised agricultural activities (e.g., wheat, barley, and other products) besides a very internationally competitive manufacturing sector. It is also characterised by high pollution (e.g., particulate emissions) due to traffic and industries and areas of soil and water degradation (https://www.arpae.it/elenco_minisiti.asp?tipo=Temi) [14,15]. On the other hand, the Apennines are quite rich in forests, but these are mostly left unused or for recreation due to their location on steep mountains and the labour force migration towards the industrialised areas of the Po Valley [16]. From a rural development perspective, the Po Valley is well developed and displays strong links between its industries and agriculture, whereas the Apennine areas are under-developed and show acute economic problems [17,18]. Regarding bioenergy, these territorial characteristics led to the adoption of two different types of bioenergy technologies and products, i.e., biogas-based electricity production (Po Valley) and forest-based bioheat production (Apennines). Eventually, the development of biogas and forest-based bioenergy has produced different outcomes, particularly in terms of the triple bottom sustainability (i.e., environmental, economic and social). Concerning biogas, some of the most critical consequences have been social opposition, a rise in farmland rent price, while the local environmental effects are bad smells, local warming and losses in soil quality $[2,8]$. On the other hand, the case of forest-based bioheat displays different features. Compared to the original situation where bioenergy production did not exist, local stakeholders say that the organisational capacity of the forestry sector is improving, local forest owners and other businesses have new sources of income, the energy bills are lower, and there is a potential reduction of $\mathrm{CO}_{2}$ emissions.

Based on this background, the study asks: "How do the two bioenergy systems differ in their governance configuration and how does this affect the capacity to deliver outcomes that are considered sustainable and desirable by the stakeholders?" The expression "bioenergy system" is intended to address the social and technical aspects of bioenergy, for instance, the technologies adopted, stakeholders involved, policies, decision-making processes, utilised biomass, etc. The study draws on the "Grounded Innovation Platform" approach (GRIP) $[10,12,19]$ and the literature on governance [20-25] to answer the research question, as will follow in the next section.

\section{Theory and Methodology}

\subsection{Theoretical Framework}

The study draws on the Grounded Innovation Approach (GRIP) which looks at innovations in the land-based economy, i.e., economies that use land and its relate natural resources, such as water, soil, trees, and so on, to produce energy, biochemicals, and other bioproducts [19]. It describes a form of innovation that is "[ ... ] grounded by the nature of its inclusiveness, power relations, and embeddedness in regional and local contexts. A GRIP is by definition an Innovation Platform, but it may also involve a cluster, user-producer interaction, and grassroots or bottom-up processes and action" [12] (p. 5). In this framework, innovation is conceived as a process that shall improve the life conditions of people in specific areas by strengthening social justice, economic benefits and environmental sustainability, i.e., triple bottom line 
sustainability (TBL) $[9,10,19,26,27]$. The regional specificity becomes particularly important (although it does exclude the cooperation with external actors or areas) because natural resources are embedded not just in rural eco-systems but also social norms, routines and other social dynamics (e.g., power relations) $[10,28,29]$. The GRIP approach makes use of two analytical dimensions to investigate the structure and capacity of a GRIP to deliver sustainable outcomes: "innovation platformeness" and "groundedness". The former refers to the idea of Innovation Platform (IP) as a learning environment [30] where actors having different forms of knowledge gather to tackle a particular problem (or problems) through a joint learning process $[10,12,19,30,31]$. Inclusion and synergies among a broad range of stakeholders and local assets (e.g., entrepreneurs, foresters, farmers on the one hand; public sector; research institutes and consumers/users and citizens) [12] (p. 6) are thus crucial factors to explore the degree of inclusive innovation. The "groundedness" dimension is connected to the normative aspect of sustainability; namely, whether the actors involved have specific triple bottom line goals, particularly about social empowerment and provision of social benefits that are embedded in the local context (economy, institutions, and values).

This understanding of innovation is rooted in the innovation systems theory $[30,32,33]$ and, within this, particularly the regional innovation systems [34-36] and inclusive innovation for sustainable development $[9,10,12,13,24,37,38]$. Innovation systems can be thought as collective learning systems, where learning by interacting [30,32] and the involvement of a wide range of actors (i.e., firms and entrepreneurs but also public bodies, civil society, research institutions, consumers, producers and users) are key to innovation. The underlying premise is that innovation is more likely to occur within a milieu characterised by embeddedness [31]. In particular, the regional innovation systems (RIS) approach assumes that geographical proximity and shared resources, such as knowledge, skills, values and trust embedded in the local milieu can foster common interests, interaction and ultimately, innovation processes. Currently, this understanding of innovation systems has conflated in the field of transition studies, which particularly focuses on the processes of change related to the climate change and bioeconomy field. There are several approaches to transition studies (e.g., multi-level governance, transitions management, pathways approach, and the geography of transitions). It can be said that transition studies regard not only the processes of technology innovation but also the long-term and territorially embedded changes in the institutional sphere and agency dynamics that shape and influence the adoption of green technologies and people's practices [28,29,39-41]. Therefore, it could be said that the GRIP approach brings a normative approach into this field and a way of thinking and evaluating whether and how green transitions benefit society from a triple bottom line perspective. In doing so, it refers to the inclusive innovation literature and reckons the existence of issues related to power-i.e., who can and does control crucial resources-which are critical to understanding how and why innovation pathways go in certain directions and produce particular outcomes $[13,38,42]$. Therefore, we can say that the structure and the way of governing the grounded innovation platform-i.e., actors, rules, responsibilities and control over core resources—can shed light on the factors that influence the capacity of bioenergy systems to deliver outcomes that are considered sustainable and desirable by the stakeholders.

This system of actors, policies and responsibilities could be otherwise called governance structure or configuration. Governance can be intended as a theory, a concept as well as a way of governing. In fact, governance is both applied in research studies as a theoretical framework and decision-making as another way of governing public and private interests. It is this latter application that makes it a particular way of governing as much as other government-based approaches represent modes of governing public issues. This paper refers to the following general understanding of governance:

\footnotetext{
"Governance refers to all processes of governing, whether undertaken by a government, market, or network; whether over a family, tribe, corporation, or territory; and whether by laws, norms, power, or language. Governance is a broader term than government because it focuses not only on the state and its institutions but also on the creation of rule and order in social practices". [23] (p. 1)
} 
To follow the GRIP approach and some of the main findings of the TRIRBON project, the study assumes that local actors and especially local authorities can play a significant role in securing the sustainable development of bioenergy systems. This is not to deny the importance of national and international actors and the relations among these, but to highlight how the actions of local stakeholders can steer the bioenergy transitions towards more sustainability. Several scholars have emphasised the role of the local level (for instance partnerships between local authorities, households, local businesses, local knowledge centres, farmers and forest owners) where important actions can be adopted to tackle climate change and enable sustainable natural resources management [22,43-47]. Bevir [48] describes this local governance as "a more or less polycentric system in which a variety of actors are engaged in local public decision-making processes" (p. 314), none of them retaining the power. In the literature on local climate change governance, most authors interrogate the role of local authorities by making an implicit assumption that local governments' intervention is crucial $[12,22,45,46,49,50]$. Four modes of local climate governance $[22,49,50]$ can be used to explore the role of local authorities: self-governing, governing through enabling, governing by provision and governing by authority. Self-governing refers to the capacity of local governments to manage their activities within the climate change sphere, for instance, energy efficiency interventions or adoption of bioheat in public buildings. Governing through enabling is the actions that a local government takes to encourage cooperation, private-public partnerships, social inclusion and awareness. Governing by provision describes the delivery of services and resources, as for instance financial schemes or infrastructural interventions. Finally, governing by authority recalls the classic task of introducing new regulations or using sanctions [22] (p. 5). In connection with the GRIP dimensions of "innovation platformness" and "groundedness", these four modes can be used to look closely at the role of local governments within grounded innovation platforms and how they can foster the capacity of bioenergy systems to secure sustainable and desirable outcomes at the local level.

\subsection{Methodology and Methods}

This study employs qualitative case study methodology [51-57] which is typically used to explore and unravel a complex or little-known phenomenon within its real-life context [54,55]. Accordingly, this case study design aims to explore the phenomenon of local governance of bioenergy development in Emilia Romagna and its capacity to deliver sustainable outcomes. The case study design is thus structured as follow. The case study is that of bioenergy development governance in Emilia Romagna, which is the geographical case study unit [54]. Both the case study and the case study unit splits into sub-categories, i.e., the case of bioenergy development governance is distinguished in biogas and forest-based bioenergy production, while the case study unit includes two geographical areas within the region, namely the Po Valley and the Apennines (sub-units) (see Figure 1). The study adopts a comparative case study design to explore the differences in the governance of bioenergy development in the two sub-case studies and understand the reasons behind different triple bottom line outcomes in the two regional sub-units (Figure 2).

The study thus compares the cases based on the local governance variable and triple bottom line sustainability dimension.

In this context, Emilia Romagna is a relevant case study unit for four main reasons:

(1) It is one of the European regions which have experienced some of the most pervasive and fast processes of biogas adoption [2,5,8,58-60], while forest-based bioenergy remains underdeveloped.

(2) It confirms the evidence that bioenergy development has also produced harmful consequences despite the expectation of several benefits for rural areas. However, the two sub-units display somewhat different sustainable outcomes.

(3) One case presents a strong connection between existing industries, such as manufacturing, food industry and sugar industry and biogas development, whereas forest-based bioenergy development does not share the same strong links with existing industrial specialisations. During industrialisation (1950s-1960s), many people left the mountains to relocate in the Po Valley. The majority of workers abandoned forestry to work in manufacturing and services; thus, forestry 
became quite marginal in the regional economic structure. The Po Valley areas became highly industrialised and many rural families invested in manufacturing leading to the creation of some of the most successful companies in Europe [61-63]. Consequently, the leading regional sectors are concentrated in the Po Valley and these are services $(56.4 \%)$, manufacturing $(29.5 \%)$ and agriculture (2.77\%, regional value added) [64]. Manufacturing specialises in natural gas infrastructure and plants, methane engines and cars components. Agriculture is currently specialised in food crops such as wheat, corn and barley [64] and the average productive property size is around $14.6 \mathrm{~h}$. These data show an increasing trend from the 2000s $(10 \mathrm{~h})$.

(4) From a governance perspective, the sub-units show two different settings regarding the development of bioenergy. Therefore, the case-study unit is believed to provide an attractive ground for exploring the research question.

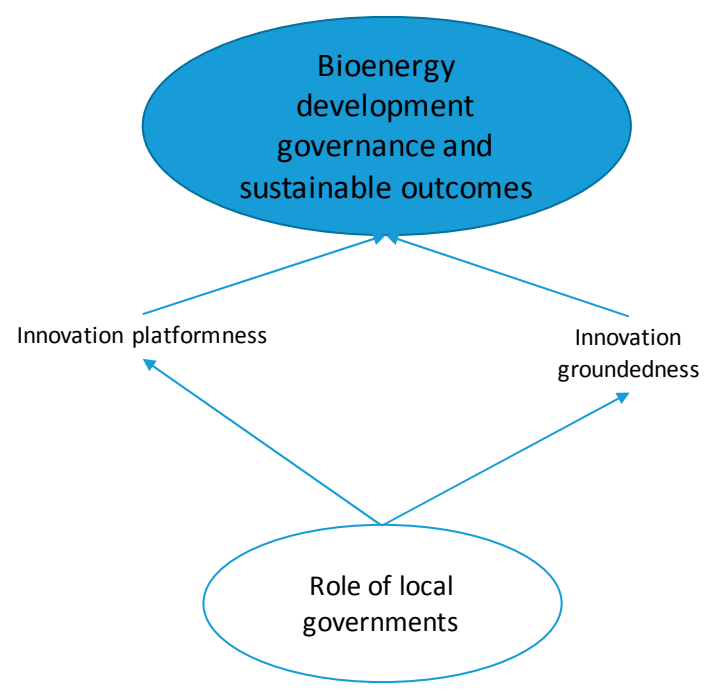

Figure 1. Theoretical framework structure.
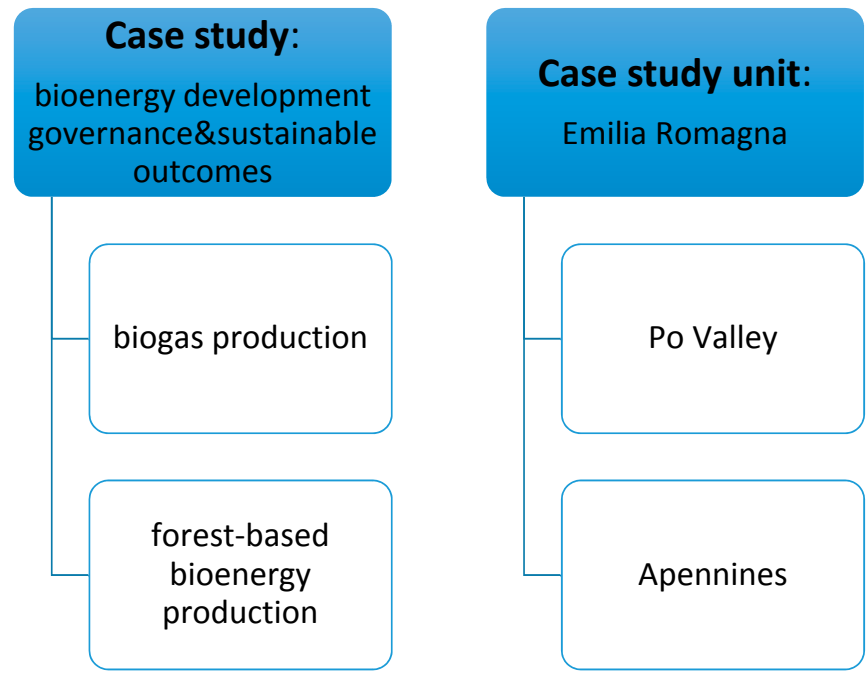

Figure 2. Case study design.

The study employs qualitative methods such as semi-structured interviews with relevant stakeholders (i.e., local and regional decision-makers, farmers' unions, interest organisations, bioenergy producers and consumers, experts, environmental organisations) and governance analysis. Governance analysis is based on the information gathered during the interviews, policy and other public documents 
(e.g., local and environmental regulations) analysis. These methods provide knowledge on the key players involved in decision-making, their responsibilities and control over critical resources and the rules they follow. Other sources of information are public documents, databases [65-73] (ISTAT (National Statistics Institute) agriculture and population statistics http://www.istat.it/en/; GSE-http://www.gse.it/en/Pages/default.aspx), statistics, and quantitative material (e.g., $\mathrm{CO}_{2}$ emissions studies, forest and land capacity). The study also makes use of the research findings from the TRIBORN project [12], the correspondent author's PhD results $[8,13,74]$ and a large body of literature on bioenergy-related issues [3,75-81]. On the one hand, the correspondent author's paper on the Emilia Romagna region [8] made use of qualitative system dynamics to investigate the causal processes of bioenergy development that led to unsustainable outcomes of biogas production in the region. A similar study is currently being undertaken in the case of forest-based bioenergy production in Emilia Romagna using the same methodology. On the other hand, a working paper on bioenergy pathways in Emilia Romagna [13] sheds light on the power relations that influence the framings (i.e., policies, technologies adopted, actors involved, and values) of bioenergy adoption, and how these affect its development and triple bottom line sustainability outcomes. Finally, the TRIBORN project provides a broad range of data and comparative results on bioenergy policies, governance and TBL outcomes in the Scandinavian countries and regions and Italy-Emilia Romagna.

Regarding semi-structured interviews, 50 stakeholders were interviewed between March 2014 and April 2015 (see Appendix A). Interviewees were selected based on previous studies [2,8,13], the TRIBORN project database and the snowball method, the latter relying on suggestions and cooperation of the previous interviewees. Although random sampling " $[$... ] may negate charges of researcher bias in the selection of participants [ ... and] help to ensure that any "unknown influences" are distributed evenly within the sample" [82] (p. 65), it can also lead to oversampling a class of informants and under-sampling others. To mitigate these effects, the selection was integrated and crosschecked with existent relevant studies $[5,58]$ and official regional databases listing bioenergy facilities and location [65].

Informants were asked to provide information on their main activities and role within the organisation. Moreover, according to the type of stakeholder, they were invited to tell about their motivations, perceptions/ideas on bioenergy development and its outcomes, especially by highlighting strengths, weaknesses, advantages, benefits and disadvantages for the region or local area and possibly to suggest an alternative way forward.

The study does not claim statistical representativeness, as the populations of all actors in the bioenergy systems are not readily identifiable from public databases. However, as the study combines different methods and data sources (i.e., interviews, public documents, reports and public databases), it is believed that this data cross-matching can ensure its reliability and validity $[51,53,54,83,84]$.

\section{Results}

\subsection{The Regional Context}

Emilia Romagna is a northeastern Italian region with 4,459,246 inhabitants and approximately $200 / \mathrm{km}^{2}$ population density. The regional administrative system includes nine provinces, 340 municipalities, 45 unions of municipalities and one mountain community (the "union of municipalities" is an association of communes that aims to coordinate and optimize the previously individual tasks. Mountain Communities are a residual administrative form in the national context. They were established in the 1970s with the intent to promote mountain areas via cooperation between mountain municipalities. Many regions have decided to abolish mountain communities as they were deemed an excessive administrative burden). As ISTAT statistics [85] show, the "Padana Plain" or Po Valley (an area that cuts across Emilia Romagna, Lombardia and Veneto) in the region accounts for approximately $48 \%$ of the regional land and the Apennines for remaining part (52\%). The Padana Plain is densely populated with an average population range of $299-674 / \mathrm{km}^{2}$ in urban (e.g., Bologna) and 
intermediate rural areas. Eurostat reports that $76.7 \%$ of the regional population inhabits intermediate rural areas. The Apennines area is sparsely populated with an average of approximately $85 / \mathrm{km}^{2}$. Based on the European definition of rural areas [86] most of the regional "intermediate rural areas" are located near urban centres of the Po Valley, while "thinly populated areas" (i.e., areas with development problems) are located in the Apennines.

The regional forested area is about $25 \%$ (560,000 ha) of the land, of which $5.2 \%$ is found in the Po Valley and the rest in the Apennines. Most of the forest resources are located on very steep ridges and have unfavourable soil conditions (i.e., erosion) that make harvesting difficult ([87]; (interviews with $[32,33]$ ). Private property is the dominant form of ownership and accounts for approximately $80 \%$ of the regional forests. The remaining $20 \%$ is public property included in protected areas [87] (pp. 11-12). Most of the forest owners have abandoned their properties to work in services or manufacturing and their descendants are commonly not aware of the ownership rights (interview with [33]). Only $52 \%$ of the private properties are located within productive farms. Due to this situation, it is hard to find data on the average forestry property. The most updated statistics only show that there are a few poplar farms in the Po Valley which average size is 5 ha [87]. Forest owners do not have any regional association to represent their interests in political arenas. The case is different for farmers who gather in three very powerful unions (Coldiretti, Confagricoltura and Confederazione Italiana Agricoltura), which represent their interests in local, regional and national political and decision-making platforms. Farmers' unions also advise their associates on different topics, from investments to production and organisational strategies.

The National and Regional Energy System

The regional energy system is mostly based on natural gas and oil for both electricity and heat generation (same figure at the national level). The natural gas grid was built during the 1950s and supported the regional industrial development. The National Energy Authority's data (AEEG) show that natural gas and oil account for $68.1 \%$ of energy consumption while renewable energy accounts for $18 \%$ indicating an increasing trend compared to 2012 (15.1\%). Available regional figures show that, in 2012, Emilia Romagna received $13.1 \%$ of the total natural gas distributed per region $\left(\mathrm{in}^{3}\right.$ ), second only to Lombardy (26.6\%). In Italy, natural gas and oil are imported from abroad (Russia, Algeria and Norway) for about $65 \%$ of total Mtoe production (national extraction has been in constant decline since at least 1997 and nowadays accounts for only 7\% of the total amount). The main actors in the national context are ENI on the natural gas side and ENEL on the electricity side. Currently, the energy market is an oligopoly (i.e., power production and import of natural gas). The main natural gas distributor is SNAM rete gas $(23.1 \%)$, whereas in the region there are other two major distributors, i.e., HERA $\left(6.5 \%\right.$ of $\left.\mathrm{m}^{3}\right)$ and IREN $\left(5.9 \% \mathrm{of}^{3}\right)$. HERA is also one of the biggest national producers of bioenergy $(5.3 \%)$.

In Italy, the state and regions have concurrent legislative competence on the Energy Policy [88]. Regarding renewable energy and bioenergy, they have been part of a national strategy that encompasses several policies, including Climate Change, Energy Security, Agriculture Growth and Innovation. The Ministry of Agriculture, Ministry of Environment and the Ministry of Economic Development in a leading position provide the overall policy framework. At the regional level, the Department of Economic Development is mostly in charge of implementing the national renewable energy policies and setting the regional guidelines, jointly with the Departments of Agriculture and Environment $[89,90]$. Based on this public governance structure, between 2009 and 2011 the Italian government set up the renewable energy policy framework that includes bioenergy [90-93] following the 2009 European Renewable Energy Directive (RES) [94]. Firstly, the National guidelines for renewable energy production remarked that provinces, regional government, the environmental agency and local health units are the key public actors involved in the governance of the biogas system, which also includes farmers' unions, biogas producers and the Italian biogas association (CIB). Municipalities, local citizens and environmental associations are excluded from this [92]. Notably, municipalities cannot influence or 
take the initiative on bioenergy decision-making, while citizens and environmental organisations are not involved in the planning. Secondly, the national government introduced a feed-in tariff scheme for biogas-based electricity production of about $0.28 €$ cent $/ \mathrm{kW}$ that is given only up to $999 \mathrm{kWe}$ installed power capacity. If a plant exceeds the threshold, it will fall within the green certificates scheme $[95,96]$. Thirdly, farm-based bioenergy production benefited of a tax exemption on bioenergy production and the possibility to cumulate different incentives up to $40 \%$ of the total investment until 2014 [97] (art. 152). To be granted the tax exemption and the incentive accumulation, bioenergy plants owners must prove to be farmers, i.e., at least $51 \%$ of the biomass fed to the plant should be from the biogas firm's fields $[98,99]$. This advantage goes along with the policy goal of supporting farmers and particularly those who have or had a connection with the sugar industry. Especially in the context of Emilia Romagna, the rural development program aims to support bioenergy production in connection to agriculture, and as several informants said, the region has redirected part of the European money for rural development to bioenergy production and pilot projects $[13,17]$. Most recently, the national government has changed the incentive schemes. The new feed-in tariff (2012) differentiates the incentive per type of biomass and prioritises agriculture by-products (e.g., residues) over energy crops and small-size plants (i.e., $1<\mathrm{P} \leq 300 \mathrm{~kW}$ ) [100]. In 2014, they also removed the tax exemption on farm-based bioenergy production.

\subsection{The Case of Biogas in Emilia Romagna}

In the Po Valley, the former driver of renewable energy production is rooted in the critical issue of energy security, which emerged during the 1970s oil crises. On the one hand, the Italian dependence on the import of fossil fuels from politically unstable countries (Russia and Algeria predominantly) and the very high cost of energy [101] triggered the commitment to support the adoption of other sources of energy. The other key drivers are the EU climate change policy (e.g., 2020 goals, [94]) and the CAP reforms, notably the 2004 reform which led to the decline of the sugar industry in Italy. The 2004 EU CAP reform strongly impacted on the national sugar production leading to the closure of 13 of 16 factories and consequent abandonment of sugar beet production (mostly based in Emilia Romagna) [102]. The reform did not only affect Emilia Romagna but the whole northeastern regions (especially Veneto and Lombardia) and Marche, which agriculture was also specialised in sugar production. This situation urged industrial and agriculture actors to demand the national and regional governments to help to create an alternative market for their products (e.g., [103,104]). Therefore, in 2004, the Emilia Romagna government issued the first Renewable Energy Act. The Act prioritised energy efficiency and renewable energy production [105] in response to the pressing demands of the agriculture sector and the first national law on renewable energy [89]. It also assigned to the regional and provincial level the key responsibilities on energy planning (e.g., concessions), whereas municipalities were left with residual duties on energy efficiency and district heating matters (e.g., support the development of the infrastructure) [89] (Art. 2, 3, 4). In 2007, the region was again a front-runner in adopting the Regional Energy Plan [106]. While the plan referred to natural gas as the principal energy source in the region (imported from Russia, Algeria and Norway), it also identified biogas and solar energy as the main energy alternatives. Ultimately, the national and regional rural development plans 2007-2013 (following the EU Regulation 1698/2005, [107]) stressed the contribution that agriculture could give to both bioenergy development and climate change mitigation while integrating the farmers' income [17] (p. 412). However, until the introduction of the feed-in tariff scheme to biogas-based electricity production in 2009, the adoption of anaerobic digestion remained quite negligible. The feed-in tariff and the tax exemption on farm-based bioenergy production boosted the farmers and other kinds of entrepreneurs' (e.g., ex-managers of sugar plants) expectation for consistent future revenues from the production of biogas (interviews [1-14]) $[2,5,8,13]$. For this reason, between 2009 and 2012 the number of biogas plants almost sextupled (29-172 plants) [8] triggering the opposition of rural areas to biogas production. Local inhabitants affirm that they tried to involve the local authorities and demand their intervention to stop or control the uncontrolled and fast diffusion 
of biogas plants (interviewees [38-41]). In some areas (e.g., Province of Bologna and Ferrara), they have formed local committees to contrast the uncontrolled diffusion of biogas plants (interviews with [38-41]) [108]. They have expressed concerns regarding the increase in energy crops production and disappearance of food production instead; the import of biomass and consequent increase of traffic in rural areas; bad smells and leachate that flowed from biomass storage units to irrigation ditches and soil and which, in their opinion, is dangerous to the environment and human health (interviews [31,38-41]). By considering the policy and public governance framework, it can be said that there were five main causes of this reaction:

- The absence of local authorities in the decision-making process which has made their role as mediators between inhabitants and regional/national governments and agencies complicated. Local governments have urban planning responsibility, but the most they could do in this case was to organise meetings with the local people and biogas businesses or take part of ad-hoc events with experts to try to cope with local opposition.

- The sugar industry crisis led many among farmers' unions, politicians and farmers to think that energy crops and biogas production could become an alternative market opportunity for those who had lost their job or primary income (interviews with [20,24-30]).

- The support scheme did not explicitly prioritised the use of a particular type of biomass but rather encouraged non-farmers and small farmers who did not have enough available land to rent it for the purpose of installing the plant facilities and cultivate energy crops (tax exemption).

- Most of the biogas producers invested in German technology which was developed for livestock farms and energy crops-also fitting quite well the Emilia Romagna agriculture features-and therefore have been using energy crops and manure [5]. The use of this biomass mix is also justified by the idea that only manure and energy crops can give the highest production efficiency [5].

- Due to weather conditions and land limitations, the in-house cultivation of energy crops has not always been constant and sufficient. Therefore, many biogas firms have had to buy biomass on the market and transport it to the facilities.

From a triple bottom line perspective, these factors have not only triggered social opposition, but also unexpected local economic and environmental issues. Firstly, one main consequence of the policy framework is the only sale and supply of electricity whereas, during the process of electricity generation, heat is also produced. Interviews show that there is very little interest in the heat supply from biogas plants. As some state (interviews with $[1-3,6-8,10,11,14,18]$ ), the distance of plants from town centres or other local buildings would make it inefficient and expensive. For several reasons, local governments are entirely passive on the matter. As mentioned the policy framework excludes local governments from the decision-making, but another core reason is that municipalities are shareholders of the two biggest regional multi-utilities that besides waste management and water supply, also control most of the transmission grid. Changing the energy source and infrastructure would involve economic and power costs that are best left untouched. Nevertheless, the unused and wasted heat remains both an environmental and economic problem for local areas (contribution to local warming) and a missed revenue for biogas producers. A second consequence seems to be the rise of farmland rent price due to the increasing demand and use of land to install the plant facilities and cultivate energy crops. As mentioned, part of the biogas investors were not former farmers (e.g., external entrepreneurs) and therefore needed to buy or rent land from them; or else in several cases, farmers did not have enough land to install the facilities and cultivate energy crops. Farmers unions say that this triggered tensions and conflicts between farmers and biogas producers. "Some farmers even had to abandon their cultivations or their land" (interviews with [24,25,27-30]). The recent statistics [109-112] seem to substantiate the interviewees' claims.

Given the situation, in 2011, the local committees handed a Moratorium to the regional government which proposed stricter environmental regulations, greater support to small-size plants that use in-house biomass supply and waste-based biomass use, and stronger social inclusion 
in the concession process [108] (interview with [31]). The regional government responded by introducing stricter environmental criteria to plant management, biomass storing and areas for plants location $[113,114]$. In the meantime, the national government changed the feed-in tariff scheme (2012) due to cuts in the national budget and removed the tax exemption on farm-based bioenergy production in 2014. The new regulatory framework only applies to new plants, meaning that most of the existing problems remain unaddressed.

\subsection{The Case of Forest-Based Bioenergy and CISA District}

In the Apennines area, the interest in bioenergy but especially in forest-based bioheat production is a result of different factors, such as the opportunities provided by the actions of the European Rural Development and Regional Development funds and a need for local actors to boost the stagnant rural economy. As previously outlined, the Apennine areas and forestry are quite marginal within the regional economic and political landscape. Since the end of the World War II (W.W. II), the industrial policy focus has been on the Po Valley industries rather than in forest and mountain areas. Over time and since the regionalisation of the forestry policy in the 1970s, the regional government has adopted a rather protective forestry policy approach to respond to the requests of the Po Valley people to maintain forests as recreational areas for their families (interviews with $[10,19,33,42,43]$ ). Notably, the forestry policy introduced rather strict criteria to forest harvesting due to the damage caused by unlimited forest use in the aftermath of W.W. II, as well as institutional and public pressures to preserve its recreational use. However, this policy only reinforced the declining process of the Apennines and led to an almost complete abandonment of forest properties (interviews with [10,33,43]).

Within this context, the European Regional and Rural Development funds gave the opportunity to local actors (e.g., the Province of Bologna) to take the initiative and foster rural development through investments in bioenergy production and climate change mitigation among other things $[14,16,18]$. Although the same policies and governance rules of the previous case apply to this one, local public and private actors could take on more planning autonomy, perhaps because forest areas are less under economic and political focus. There are some more or less successful experiences in the Apennines (interviews with $[42,43]$ ) but the most structured and famous one is that of the Porretta Terme District.

In 2004, the Province of Bologna, local development bank CA.RI.SBO, and the Italian Institute for Sustainable Development constituted the local Centre for Environmental Innovation (CISA), a consortium that gathered 11 municipalities in the Province of Bologna (interview with [19,33]. The goal was to create a local renewable energy district that could become a pivotal example of the benefits of local renewable energy production and environmentally-friendly practices. Notably, the Consortium pointed at forest-based bioenergy production as a strategic asset for rural development and concentrated its efforts to develop a sustainable and efficient system. Small forest-based bioenergy plants and district heating facilities were installed in the partner municipalities (e.g., Castiglione dei Pepoli), as well as small-scale hydropower generation plants and power stations for sun-fuelled cars [115]. This has triggered the organisation of local forest owners and forest businesses into a Forestry Consortium called EPAV, which has 30 associates. The Consortium provides advisory and technical services to forest owners and businesses, but also to local bioenergy plants (interview with [32]). Moreover, the consumption of bioheat seems to reduce the energy bills where the bioheat plant was installed after a local call for tenders. EPAV leader says, "usually these call for tenders include a clause that prohibits operators from setting a bioheat price higher than conventional fuel" (interview with [32]). Bioenergy production gained the support of local actors thanks to the inclusion of different local stakeholders, such as foresters, businesses and schools, and the benefits that delivered to the whole local community.

Over time, CISA has grown (i.e., 17 municipalities) and become a local "centre of competence" that specialises in organisational and technology innovation, knowledge exchange and research projects. Recently, CISA has merged with another local centre (i.e., "Energy and Sustainable Development Agency of Modena") to constitute an inter-municipal Energy Agency that includes municipalities 
from Modena and Bologna Provinces (interview with [32,33]). In the wake of the successful experience of CISA and other peripheral cases in the region, the regional government-particularly the Department of Environment-has recently decided to more actively support the forest biomass and bioenergy production.

In other Apennine areas, such as Casola Valsenio (Province of Ravenna), local actors (i.e., forest owners, forest cooperatives and municipalities) had more troubles to start the production of bioenergy and develop a stable biomass supply than in the Porretta Terma District (interviews with $[42,43]$ ). The municipality of Casola Valsenio together with a local farmers' union and forest owners' cooperative were the main initiator of the bioenergy project in the area. The project included the construction of a district-heating network for supplying heat to nine public buildings. However, it had to be resized due to a reduction of available finances apparently connected to the lack of a structured collaboration between the region and the municipality (interview with [42]). Eventually, they only installed a wood-based bioenergy plant that supplies heat to a local school. The local forest cooperative provides the biomass (interview with [43]), although they do not find a very remunerative business because the facility is too small and does not demand much material (i.e., the supply exceeds the demand). The biggest problems have been the lack of a coordinated framework between public authorities at different levels, namely the municipality, province and region. Moreover, whereas in Porretta Terme the creation of CISA made possible to more easily access the EU funds, the case of Casola Valsenio did not see the presence of a knowledge centre such as CISA.

Based on these findings, forest-based bioenergy has produced more consistent triple bottom line benefits than biogas although there are different regional cases. From an economic point of view, bioenergy production has led to the creation of new local businesses, such as the local forestry consortium (EPAV), the forest cooperative Valle Senio and a local energy company (ARS Energy: Casola Valsenio, Italy). This also means that the local forestry sector is better organised (e.g., better forest management, harvesting procedures and machinery) than it was before the adoption of bioenergy plants. The income of forestry activities has increased, although businesses struggle with logistics, machinery and equipment or a relatively too small local bioenergy market. Nevertheless, bioenergy consumption lowers the energy bill, and the local production increases energy flexibility and supply security (interviews with $[32,33,42,43]$ ).

From a social perspective, improvements can be seen in the rise of local awareness on bioenergy, the development of a local forest value chain and climate change. There has been some local malcontent and opposition in certain areas regarding, for instance, the emissions from the plant chimneys, but these social instances were resolved quite quickly (interview with [33,42]), save in one case where the plant could not be installed. The use of forest resources has gained the attention of local citizens, who were not used to forestry activities, and regional policy-makers, who have started seeing a considerable economic potential in local forest-based bioenergy production.

Environmentally, there seem to be both positive and negative outcomes. Harvesting activities inevitably have an impact on soil nutrients, but on the other hand, the choice to harvest primarily certain species of wild trees (e.g., "Robinia pseudoacacia") may eventually increase the biodiversity in the areas. On the positive side, the replacement of fossil fuels will eventually decrease greenhouse gas emissions. However, local citizens demand that particulate emissions from the plants be kept under constant control (interview with [32,33,43]).

\section{A Best and Worst Practice in the Bologna Apennine}

Castiglione dei Pepoli was an early adopter of bioheat in the Bologna Apennine area. As a partner of CISA, the local government of Castiglione dei Pepoli (Province of Bologna) decided to support the construction of a wood-based district heating (DH) facility of $340 \mathrm{kWh}$ power capacity. In November 2007, CISA and the Municipality of Castiglione signed an agreement, which also involved the local school buildings (i.e., primary school, secondary school and nursery), CO.SE.A (local environmental services consortium) and a local forestry company (Le Fontanelle: Castiglione dei 
Pepoli, Italy, http:/ / www.agroforestale-le-fontanelle.it/). The municipality signed a contract with an ad-hoc established Energy Service Company (Ars Energy) as part of CO.SE.A, for 10 years.

In 2007, the Regional Rural Development Plan [17] provided new funds to support rural environmental projects, in particular for the "construction of public facilities for the production of energy from local biomass" (Action3, Measure 321). Therefore, the former stakeholders (i.e., Castiglione dei Pepoli Municipality, CISA and Le Fontanelle) decided to build another forest-based DH facility to supply heat to the public buildings in Lagaro (kindergarten and school gym). "Le Fontanelle" would pro Action ide wood chips from local forests (less than $40 \mathrm{~km}$ ), while the municipality signed a 15 years contract with Ars Energy. Given the positive development of these former projects, in 2012 the local government proposed to expand the district-heating network by building a new CHP plant of up to 1 MW power capacity. The project involved CISA, the local government of Castiglione dei Pepoli, a newly funded energy company Castiglione Bioenergie Ltd (Castiglione dei Pepoli, Italy) and the local forestry company. Currently, the new DH supplies heat also to private customers (e.g., private households). However, the power generation station is not yet active due to technical issues in the gasification process.

Monterenzio is a rather different case compared to Castiglione dei Pepoli. In 2012, the owner of a Thermal SPA ("Acquapark della Salute") planned to install a 3 MWh CHP forest-based bioenergy plant. The SPA facilities were supposed to use the heath (i.e., indoor pools, outdoor swimming pools, spa services and also restaurants). The SPA is part of a rather big rural property located in the Sillaro Valley, which includes both forests and farmland. Therefore, the plan was to use biomass from the farm's agriculture and forestry by-products (coppice and fast-growing poplar, chestnuts and pruning).

The main goals of the local entrepreneur were to diversify its business by taking advantage of the feed-in tariff scheme for bio-based electricity production and re-use the farm's own by-products, as well as cutting the costs of the natural gas bill. Although the company was granted the concession to build the plant in 2013, the project was not finalised because of the rising social opposition. Local inhabitants gathered in a committee named "Save the Sillaro" supported by the Mayor who was very anxious about the potential consequences of bioenergy production. The residents considered the plant too big compared to the biomass supply capacity and were concerned about particulate emissions. As a result, the local government modified the "local building regulation" to impose a minimum distance between future bioenergy facilities and local private and public buildings. The new provisions established that bioenergy plants of above $200 \mathrm{~kW}$ should be located at least two-kilometres from the urban centre and $500 \mathrm{~m}$ from detached houses. Monterenzio was the first municipality in the Province of Bologna to approve a regulatory document regarding bioenergy land planning.

This case brought the Union of Municipalities of Savena-Idice (Loiano, Monghidoro, Monterenzio e Pianoro) to start a participatory process by taking advantage of the new regional funding for participatory processes [116]. The goal was to prepare a joint regulation on renewable energy development and energy efficiency. The participatory process thus involved local committees, farmers' unions, business organisations (e.g., Confederazione Nazionale Artigiani, CNA), local environmental agencies and private associations, local businesses and CISA. The final document [116] indicates the priorities on the use of renewable energy sources and particularly emphasises the adoption of solar and geothermal technologies. Regarding the adoption of bioenergy plants, the document requires the application of stricter environmental criteria to evaluate and monitor particulate emissions from the concession process to the actual production of bioenergy (interview with [22,33]).

\section{Discussion}

This section discusses the governance of bioenergy development focusing on the involvement of local authorities and its impact on grounded innovation (i.e., innovation platformness and groundedness).

The case of biogas development does not show any of the four modes of the local governance of climate change, namely self-governing, governing through enabling, governing by provision and 
governing by authority. The reason partially lays in the national and regional laws that interdict the intervention of local governments in renewable energy planning, but the comparison with the case of forest-based bioenergy production raises some doubts whether this is the only plausible explanation. Most likely, rural municipalities have found themselves trapped in a bundle of institutional and power constraints. On the one hand, there have been farmers and farmers' unions that were, at least initially, strongly encouraging biogas development. Beyond this, local authorities could not intervene in bioenergy planning by law, while other agencies have been in charge of the process (i.e., regional government, environmental agency, local health units). Additionally, the membership in the regional multi-utilities (HERA and IREN) has hindered the local administrations' interest to find biomass alternatives to energy crops (e.g., organic fraction or urban waste), use of biogas plants heat and lobby for biomethane production and supply. Essentially, local governments have both been marginalised by other actors and prevented themselves from playing a more assertive role. Regarding the "innovation platformness" and "groundedness" dimensions, while this local governance configuration includes regional and local resources (such as human, natural and financial resources, knowledge and social networks) it does not see the active participation of local authorities and citizens in the decision-making and planning processes. There is also a consequent lack of coordination between scales and actors. A compelling example is the absence of local heat supply. The exclusion of local actors such as municipalities and citizens makes them unaware of the benefits of local heat supply and not at all interested in this option. Furthermore, the absence of effective local governance is combined with one-size-fits-all financial support schemes. The feed-in tariff and the tax exemption on farm-based bioenergy production have boosted future economic gain but have done very little in terms of broader rural development goals. In this context, innovation takes the form of technology adoption, product innovation (i.e., farmers move into energy production) and, in some cases organisational innovation in the traditional sense, namely changes in the internal organisation of the farm (e.g., new property structures). Indeed, some stakeholders have attained new knowledge. For instance, most of the interviewed farmers have learned how to best organise anaerobic digestion from both a technical and biological point of view (i.e., the feedstock mix and timing). Additionally, the regional environmental agency has gained insights on the local environmental effects of biogas plants and biomass mismanagement, e.g., loss in soil quality, local warming and bad smells. Nonetheless, the result has been the failure in creating a local innovation platform and producing triple bottom line benefits. Various actors are involved, but they do not fully cooperate or coordinate their actions-decisions to reach common goals and issues. Seemingly, many actors have improved their knowledge or taken actions but fairly in disconnection to the others. Moreover, although the emergence of social opposition has, to some extent, opened up a corridor for local claims (see for instance the Moratorium) the system remains hesitant to welcome bottom-up and local experiences that could foster more systemic and sustainable outcomes.

The case of forest-based bioenergy production shows different patterns. It could be said that the local authorities' role has been more proactive; particularly, the modes of self-governing and governing through enabling stand up in this case. The governing by authority mode (see the case of Monterenzio) is also observable but to a minor degree. Perhaps as a consequence of the limited role of forestry in the region, the development of forest-based bioenergy production has been aloof from industrial and political interests and more favourable to local interests and actors. Since the beginning, the objectives aimed to revitalise the economy of marginal rural areas and raise climate change awareness. The governance configuration sees stronger cooperation between local human, natural and financial resources, but also local technical knowledge and skills. The innovation platform is thus more inclusive and triple bottom line-oriented. Innovation processes not only concern the traditional technological, process and product innovation, but grounded and systemic innovation. In fact, when bioenergy projects started, local knowledge and the forestry organisational model were inadequate to support bioenergy development. Forestry was characterised by fragmented properties, few businesses and almost no public interest in these activities. CISA's actions to support technology adoption, social 
learning and networking have enhanced the forestry organisational structure, local cooperation, public and political awareness about forestry and sustainability [18] (Interviews with [10,32,33]). Nevertheless, the case of forest-based bioenergy also confirms that creating an innovation system where there is no pre-existent condition (e.g., industrial links) for its development might be very difficult and unfruitful.

\section{Policy Conclusions and Recommendations}

This study aimed to understand the impact that local governance and, in particular, the role of local governments in fostering grounded innovation and triple bottom line sustainability in the case of bioenergy development in Emilia Romagna, and more generally in the bioeconomy.

Although the scope of the study is limited to a region, it investigated two cases of bioenergy production systems, i.e., biogas-based electricity and forest-based bioheat production from which some crucial lessons and policy implications can be drawn. From the governance perspective, local governments and partnerships between different stakeholders are important to provide the transition to bioenergy with a safe environment for its stable development. The inclusion of and collaboration between local stakeholders and the creation of partnerships are another factor that seems to increase the likelihood of a successful transition process and, most importantly, the delivery of desirable and sustainable benefits to local areas. As municipal members usually have a deep knowledge of their territory, they may ensure that local energy needs, environmental conditions, social and economic issues are taken into account when setting realistic targets and goals. However, in the cases where municipalities are not legally allowed to take binding actions, they can be mediators between stakeholders, the regional government and the local inhabitants or become example of best practices (e.g., adopt bioenergy in public buildings, solar panels and so on). The case of forest-based bioenergy shows that an active role of municipalities and knowledge centres can foster learning processes, inclusion and a better resolution of conflicts. On the opposite, where this role cannot be or is not accomplished, social opposition and triple bottom line unsustainability may rise, as demonstrated by the case of biogas in Emilia Romagna. However, despite the active role of local authorities, if there is no pre-existing industrial base somewhat related to bioenergy (e.g., food industry, agriculture, forestry, sawmills, and pulp and paper), it may be complicated to carry on the transition and the delivery of sustainable outcomes, as in the case of forest-based bioenergy production.

Based on these conclusions, the study would make the following policy recommendations, applicable both to bioenergy systems and the broader bioeconomy. While central governments can facilitate the development of a clear and common policy framework (e.g., key objectives, targets, short and long term goals), local and regional public authorities could adopt a variegated and locally-adapted portfolio of initiatives. Firstly, they could exploit their knowledge of the local economic and social base to include a variety of relevant actors. Connectedly, they could (or ask to local research centres or other organisations) map the existing industrial side-streams and by-products in the region to increase the utilisation of industrial waste as a substitute for raw materials. This initiative could eventually foster links between old and new industries (industrial symbiosis). This may contribute to developing new business opportunities based on collaboration between forestry-agriculture and other industries. Secondly, they could become role models by implementing good practices (e.g., adoption of solar panels, bioheat consumption, electric cars and so on) and making use of local public procurement tools (e.g., ecobudget; local energy plan; and local energy, environmental or climate change indexes). On this line, they may introduce regulations to promote the development of local biomass supply chains or alleviate the environmental impact of bioenergy production (e.g., regulate on the distance of plants from the city centre and other households). Thirdly, they could secure a long-term local commitment to bioenergy and other bioproducts, for instance by supporting the connection to existing district heating facilities or the installation of bioenergy plants engines closer to buildings that could use the heat. On this line, they could foster the accessibility to local and cost-efficient biomass supply, for instance through public tenders for the use of local biomass to benefit the circular economy. Finally, local authorities could support the creation of green labels or brands based on the international 
acknowledgement of the municipality "green" performance and image. It could foster cooperation and attract other investors and new companies.

Further research could study and compare other cases to see whether there are common patterns and investigate more extensively the link between local governance and triple bottom line sustainability of bioeconomy activities. Additionally, it could investigate the multi-level dynamics and polycentrism more in-depth to provide a deeper understanding of the impact of governance configurations on the sustainable development of the bioeconomy.

Acknowledgments: We would like to thank the Norwegian Institute of Bioeconomy Research for funding this PhD project and study via the research project TRIBORN based on the funds of the Norwegian Research Council.

Author Contributions: Bianca Cavicchi did the field research (interviews); policy and governance analysis; structured the paper and wrote all the sections and paragraphs. Policy conclusions are a result of the three authors' collaboration. Sergio Palmieri and Marco Odaldi particularly provided data (qualitative and quantitative) and scientific knowledge on Sections 4.1 and 4.3. Policy conclusions are a result of the three authors' collaboration.

Conflicts of Interest: The authors declare no conflict of interest.

\section{Appendix A. Key Interviewees}

Table A1. List of Interviews.

\begin{tabular}{|c|c|c|c|}
\hline Informants & Area & Date & Reference \\
\hline Bioenergy Businesses & Province & & \\
\hline biogas cooperative & Bologna & $24 / 11 / 2014$ & [1] \\
\hline biogas cooperative & Bologna & $15 / 09 / 2014$ & [2] \\
\hline biogas cooperative & Bologna & $22 / 09 / 2014$ & [3] \\
\hline biogas cooperative & Reggio Emilia & $07 / 11 / 2014$ & [4] \\
\hline $\begin{array}{l}\text { HERA multi-utility (Since 2002, Hera combines public service } \\
\text { companies (11 of them operating in Emilia-Romagna) into a } \\
\text { single multi-utility. Nowadays, Hera is one of Italy's largest local } \\
\text { utilities and operates mainly in Environmental services (waste } \\
\text { collection and treatment), Energy services (distribution and sale of } \\
\text { electricity and gas) and Water services (waterworks, sewerage and } \\
\text { purification). http://eng.gruppohera.it/group/who_we_are/) }\end{array}$ & Bologna & $11 / 02 / 2015$ & [5] \\
\hline biogas firm & Bologna & $02 / 12 / 2014$ & [6] \\
\hline biogas firm & Bologna & $11 / 09 / 2014$ & [7] \\
\hline biogas firm & Ferrara & $24 / 11 / 2014$ & [8] \\
\hline $\begin{array}{l}\text { IREN-multi-utility (IREN, a multiutility company listed on the } \\
\text { Italian Stock Exchange, operates in the sectors of electricity } \\
\text { (production, distribution and sale), thermal energy for district } \\
\text { heating (production and sale), gas (distribution and sale), the } \\
\text { management of integrated water services, environmental services } \\
\text { (collection and disposal of waste) and services for the local } \\
\text { authorities. Iren is structured as an industrial holding with its } \\
\text { main corporate offices in Reggio Emilia, operating units in Genoa, } \\
\text { Parma, Piacenza, and Turin, and separate companies in charge of } \\
\text { the individual business lines. Holding company, Iren handles } \\
\text { strategic, development, coordination and monitoring activities, } \\
\text { while the operating companies ensure the coordination and } \\
\text { development of the business lines. } \\
\text { http://www.gruppoiren.it/chi_siamo.asp) }\end{array}$ & Parma & $06 / 03 / 2015$ & [9] \\
\hline biogas firm & Ferrara & $21 / 10 / 2014$ & [10] \\
\hline biogas cooperative & Reggio Emilia & $\begin{array}{c}09 / 10 / 2014 \\
\text { and updated on } \\
11 / 11 / 2014\end{array}$ & [11] \\
\hline biofuel cooperative & Ravenna & 05/08/2014 & [12] \\
\hline bioenergy cooperative & Ravenna & $10 / 11 / 2014$ & [13] \\
\hline biogas firm & Ferrara & $29 / 07 / 2014$ & [14] \\
\hline
\end{tabular}


Table A1. Cont.

\begin{tabular}{|c|c|c|c|}
\hline Informants & Area & Date & Reference \\
\hline \multicolumn{4}{|l|}{ Public institutions } \\
\hline Regional Environmental Agency (ARPA) & Bologna (regional council) & $21 / 11 / 2014$ & [15] \\
\hline Regional Environmental Agency—Province Section (ARPA) & Bologna & $28 / 11 / 2014$ & [16] \\
\hline Municipal Council & Ferrara & $03 / 11 / 2014$ & [17] \\
\hline Municipal Council & Medicina (Bologna) & $21 / 11 / 2014$ & [18] \\
\hline Department of Environment & Bologna (regional council) & $18 / 02 / 2015$ & [10] \\
\hline Department of Environment & Bologna (municipal council) & 09/02/2015 & [19] \\
\hline Department of Economic Development-Energy Section & Bologna (regional council) & $20 / 10 / 2014$ & [20] \\
\hline Municipal Council & Ravenna (in the province of) & $02 / 10 / 2014$ & [21] \\
\hline Municipal Council & Bologna (in the province of) & $13 / 03 / 2015$ & [22] \\
\hline Department of Environment & Province of Ferrara & & [23] \\
\hline Municipal Council & Province of Ravenna & $02 / 10 / 2014$ & [42] \\
\hline \multicolumn{4}{|l|}{ Farmers Unions and Interest Organizations } \\
\hline CIA (regional office) & Bologna & $24 / 02 / 2012$ & [24] \\
\hline CIA & Ferrara & $10 / 12 / 2014$ & [25] \\
\hline Italian Biogas Consortium (CIB) & Milano & $23 / 06 / 2014$ & [26] \\
\hline CNA Emilia Romagna & Bologna & $29 / 10 / 2014$ & [27] \\
\hline COLDIRETTI (regional office) & Bologna & $02 / 02 / 2015$ & [28] \\
\hline COLDIRETTI & Ferrara & $29 / 07 / 2014$ & [29] \\
\hline Confagricoltura (regional office) & Bologna & $21 / 11 / 2014$ & [30] \\
\hline Legambiente & Bologna & $28 / 02 / 2012$ & [31] \\
\hline EPAV & Porretta Terme & $\begin{array}{c}3 / 11 / 2014 \\
\text { updated in } \\
11 / 02 / 2015\end{array}$ & [32] \\
\hline Forest-owners cooperative & Ravenna & $10 / 11 / 2014$ & [43] \\
\hline \multicolumn{4}{|l|}{ Research centers and Innovation platforms } \\
\hline CISA & Bologna & $\begin{array}{c}03 / 11 / 2014 \\
\text { updated in } \\
24 / 08 / 2014\end{array}$ & [33] \\
\hline ASTER (Emilia Romagna) & Bologna & $22 / 09 / 2014$ & [33] \\
\hline University of Ferrara (Economic History) & Ferrara & 06/08/2014 & [34] \\
\hline CRPA & Reggio Emilia & $30 / 05 / 2014$ & [35] \\
\hline $\begin{array}{l}\text { University o Bologna (History of Regional Economic } \\
\text { Development) }\end{array}$ & Bologna & $17 / 04 / 2014$ & [36] \\
\hline University of Bologna (History of the Energy System) & Bologna & $16 / 06 / 2014$ & [37] \\
\hline \multicolumn{4}{|l|}{$\begin{array}{l}\text { Local Commitees } \\
\end{array}$} \\
\hline Comitato Argenta & Ferrara & $\begin{array}{c}12 / 03 / 2012 \\
\text { updated in } \\
\text { January } 2015\end{array}$ & [38] \\
\hline Comitato Galliera & Bologna & $05 / 12 / 14$ & [39] \\
\hline Comitato Vigarano & Ferrara & $\begin{array}{c}12 / 03 / 2015 \\
\text { updated in } \\
\text { January } 2015\end{array}$ & [40] \\
\hline Comitato Sgonfia il Biogas & & $23 / 09 / 2014$ & [41] \\
\hline
\end{tabular}

\section{References}

1. Organisation for Economic Co-operation and Development (OECD). Linking Renewable Energy to Rural Development; OECD: Paris, France, 2012.

2. Cavicchi, B.; Bryden, J.M.; Vittuari, M. A comparison of bioenergy policies and institutional frameworks in the rural areas of Emilia Romagna and Norway. Energy Policy 2014, 67, 355-363. [CrossRef]

3. Batel, S.; Devine-Wright, P.; Tangeland, T. Social acceptance of low carbon energy and associated infrastructures: A critical discussion. Energy Policy 2013, 58, 1-5. [CrossRef]

4. Buchholz, T.; Luzadis, V.A.; Volk, T.A. Sustainability criteria for bioenergy systems: Results from an expert survey. J. Clean. Prod. 2009, 17 (Suppl. S1), S86-S98. [CrossRef] 
5. Carrosio, G. Energy production from biogas in the Italian countryside: Policies and organizational models. Energy Policy 2013, 63, 3-9. [CrossRef]

6. Upreti, B.R.; Van Der Horst, D. National renewable energy policy and local opposition in the UK: The failed development of a biomass electricity plant. Biomass Bioenergy 2004, 26, 61-69. [CrossRef]

7. Upreti, B.R. Conflict over biomass energy development in the United Kingdom: Some observations and lessons from England and Wales. Energy Policy 2004, 32, 785-800. [CrossRef]

8. Cavicchi, B. Sustainability that backfires: the case of biogas in Emilia Romagna. Environ. Innov. Soc. Transit. 2016, 21, 13-27. [CrossRef]

9. Elkington, J. Partnerships from Cannibals with Forks: The Triple Bottom line of 21 st Century Business. Environ. Qual. Manag. 1997, 199, 37-51.

10. Bryden, J.; Gezelius, S.S. Innovation as if people mattered: The ethics of innovation for sustainable development. Innov. Dev. 2017, 7, 1-18. [CrossRef]

11. Clarke, N.; Gundersen, P.; Jönsson-belyazid, U.; Kjønaas, O.J.; Persson, T.; Sigurdsson, B.D.; Stupak, I.; Vesterdal, L. Forest Ecology and Management Influence of different tree-harvesting intensities on forest soil carbon stocks in boreal and northern temperate forest ecosystems. For. Ecol. Manag. 2015, 351, 9-19. [CrossRef]

12. Bryden, J.M.; Cavicchi, B.; Kvakkestad, V.; Prestvik, A.-S.; Refsgaard, K. Towards Inclusive Innovation Praxis in Forest-based Bioenergy. In Proceedings of the 13th Globelics International Conference "Innovation to Reduce Poverty and Inequalities for Inclusive and Sustainable Development"—Globelics Havana 2015, Havana, Cuba, 23-25 September 2015.

13. Cavicchi, B.; Ely, A. Framing and Reframing Sustainable Bioenergy Pathways: The Case of Emilia Romagna; STEPS: Brighton, UK, 2016; pp. 1-32.

14. Regional Directorate General for Agriculture and Fishery. Italy-Rural Development Programme (Regional)_Emilia Romagna; Regional Directorate General for Agriculture and Fishery: Bologna, Italy, 2015.

15. Secondo Piano Triennale di Attuazione del Piano Energetico Regionale 2011-2013. Available online: http:/ / partecipazione.regione.emilia-romagna.it/entra-in-regione/progetti/piano-triennale-diattuazione-del-piani-energetico-regionale-2011-2013 (accessed on 23 February 2017). (In Italian)

16. Assessorato all'Amebiente della Regione Emilia Romagna. Piano Forestale Regionale 2014-2020; Regione Emilia Romagna: Bologna, Italy, 2014. (In Italian)

17. Ministry of Agriculture Food and Forestry. Italy Rural Development Programme; Ministry of Agriculture Food and Forestry: Rome, Italy, 2015.

18. Direzione Generale Agricoltura E.R. Programma Di Sviluppo Rurale 2007-2013, Reg (CE) 1698/2005. Available online: https://www.regione.sardegna.it/documenti/1_38_20150416132544.pdf (accessed on 23 February 2017). (In Italian)

19. Bryden, J.; Gezelius, S.; Refsgaard, K. Governing Innovation for Sustainable Development: Designing Creative Institutions; Norwegian Agricultural Economics Research Institute (NILF): Oslo, Norway, 2013; pp. 1-26.

20. Jordan, A.J.; Huitema, D.; Hildén, M.; van Asselt, H.; Rayner, T.J.; Schoenefeld, J.J.; Tosun, J.; Forster, J.; Boasson, E.L. Emergence of polycentric climate governance and its future prospects. Nat. Clim. Chang. 2015, 5, 977-982. [CrossRef]

21. Huitema, D.; Adger, W.N.; Berkhout, F.; Massey, E.; Mazmanian, D.; Munaretto, S.; Plummer, R. The governance of adaptation: Choices, reasons, and effects. Introduction to the special feature. Ecol. Soc. 2016, 21, 37. [CrossRef]

22. Kern, K.; Alber, G. Governing Climate Change in Cities: Modes of Urban Climate Governance in Multi-level Systems. Compet. Cities Clim. Chang. 2009. [CrossRef]

23. Bevir, M. A Theory of Governance; GAIA Books: Berkeley, CA, USA, 2013; Volume 26, Available online: http:/ / escholarship.org/uc/item/2qs2w3rb (accessed on 23 February 2017).

24. Understanding Governance: Pathways to Sustainability. Available online: http://steps-centre.org/wpcontent/uploads/final_steps_governance.pdf (accessed on 1 March 2016).

25. Hoppe, T.; Graf, A.; Warbroek, B.; Lammers, I.; Lepping, I. Local governments supporting local energy initiatives: Lessons from the best practices of Saerbeck (Germany) and Lochem (The Netherlands). Sustainability 2015, 7, 1900-1931. [CrossRef]

26. Slaper, T.F.; Hall, T.J. The Triple Bottom Line: What Is It and How Does It Work? Indiana Bus Rev. 2011, $86,4-8$. 
27. Bryden, J.; Arandia, A.; Johnson, T. Theoretical and policy background to the top-mard project (towards a policy model of multifunctional agriculture and rural development). In Proceedings of the 107th EAAE Seminar Modelling of Agricultural and Rural Development Policies, Sevilla, Spain, 29 January-1 February 2008; pp. 1-11.

28. Avelino, F.; Wittmayer, J.M. Shifting Power Relations in Sustainability Transitions: A Multi-actor Perspective. J. Environ. Policy Plan. 2015, 7200, 1-23. [CrossRef]

29. Grin, J.; Rotmans, J.; Schot, J. On patterns and agency in transition dynamics: Some key insights from the KSI programme. Environ. Innov. Soc. Transit. 2011, 1, 76-81. [CrossRef]

30. Lundvall, B.-Å. Innovation System Research and Policy Where It Came from and Where It Might Go; CAS Seminar: Oslo, Norway, 2007; Volume 50.

31. Cooke, P.; Gomez Uranga, M.; Etxebarria, G. Regional innovation systems: Institutional and organisational dimensions. Res. Policy 1997, 26, 475-491. [CrossRef]

32. Lundvall, B.-Å.; Johnson, B.; Andersen, E.S.; Dalum, B. National systems of production, innovation and competence building. Res. Policy 2002, 31, 213-231. [CrossRef]

33. Jensen, M.B.; Johnson, B.; Lorenz, E.; Lundvall, B.Å. Forms of knowledge and modes of innovation. Res Policy. 2007, 36, 680-693. [CrossRef]

34. Cooke, P. Regional innovation systems, clusters, and the knowledge economy. Ind. Corp. Chang. 2001, 10, 945-974. [CrossRef]

35. Doloreux, D. Regional Innovation Systems: A Critical Review; Maastricht MERIT: Maastricht, The Netherlands, 2004; Volume 190, pp. 1-26. Available online: http://www.ulb.ac.be/soco/asrdlf/documents/RIS_ Doloreux-Parto_000.pdf (accessed on 23 February 2017).

36. Moodysson, J.; Zukauskaite, E. Institutional Conditions and Innovation Systems: On the Impact of Regional Policy on Firms in Different Sectors. Reg. Stud. 2012, 48, 1-12. [CrossRef]

37. Scoones, I.; Leach, M.; Smith, A.; Stagl, S.; Stirling, A.; Thompson, J. Dynamic Systems and the Challenge of Sustainability. Available online: http://steps-centre.org/wp-content/uploads/final_steps_dynamics.pdf (accessed on 1 March 2016).

38. Byrne, R.; Smith, A.; Watson, J.; Ockwell, D. Energy Pathways in Low-Carbon Development: From Technology Transfer to Socio-Technical Transformation; STEPS: Brighton, UK, 2011; pp. 1-96.

39. Geels, F.W.; Martin, H.; Coenen, L.; Smith, A.; Voß, J.P.; Grin, J.; Coleman, G.; Karnøe, P.; Garud, R.; Loorbach, D. Processes and patterns in transitions and system innovations: Refining the co-evolutionary multi-level perspective. Res. Policy 2012, 39, 955-967. [CrossRef]

40. Geels, F.W. Technological transitions as evolutionary reconfiguration processes: A multi-level perspective and a case-study. Res. Policy 2002, 31, 1257-1274. [CrossRef]

41. Truffer, B.; Murphy, J.T.; Raven, R. The geography of sustainability transitions: Contours of an emerging theme. Environ. Innov. Soc. Transit. 2015, 17, 63-72. [CrossRef]

42. Leach, M.; Scoones, I.; Stirling, A. Dynamic Sustainabilities: Technology, Environment, Social Justice (Pathways to Sustainability); Routledge: Abingdon, UK, 2010.

43. Granberg, M.; Elander, I. Local Governance and Climate Change: Reflections on the Swedish Experience. Local Environ. 2007, 12, 537-548. [CrossRef]

44. Ostrom, E. A polycentric approach for coping with climate change. Ann. Econ. Financ. 2014, 15, 97-134.

45. Bulkeley, H.; Kern, K. Local Government and the Governing of Climate Change in Germany and the UK. Urban Stud. 2006, 43, 2237-2259. [CrossRef]

46. Nilsson, A.E.; Gerger Swartling, Å.; Eckerberg, K. Knowledge for local climate change adaptation in Sweden: challenges of multilevel governance. Local Environ. 2012, 17, 751-767. [CrossRef]

47. Glaas, E.; Jonsson, A.; Hjerpe, M.; Andersson-Sköld, Y. Managing climate change vulnerabilities: Formal institutions and knowledge use as determinants of adaptive capacity at the local level in Sweden. Local Environ. 2010, 15, 525-539. [CrossRef]

48. Bevir, M. The SAGE Handbook of Governance. In The Sage Handbook of Governance; SAGE Publications Ltd.: Thousand Oaks, CA, USA, 2011; pp. 313-329. [CrossRef]

49. Bulkeley, H.; Betsill, M. Rethinking Sustainable Cities: Multilevel Governance and the "Urban" Politics of Climate Change. Environ Politics 2005, 14, 42-63. [CrossRef]

50. Sippel, M.; Jenssen, T. What about local climate governance? A review of promise and problems. Soc. Sci. Res. Netw. 2009, 98. [CrossRef] 
51. Silverman, D. Interpreting Qualitative Data/David Silverman; Sage Publications: London, UK, 2015.

52. Bennett, A.; Elman, C. Qualitative Research: Recent Developments in Case Study Methods. Annu. Politcal Sci. Rev. 2006, 9, 455-476. [CrossRef]

53. George, A.L.; Bennett, A. Case Studies and Theory Development in the Social Sciences; MIT Press: Cambridge, MA, USA, 2005.

54. Yin, R.K. Case Study Research: Design and Methods; Bickman, L., Rog, D.J., Eds.; Sage Publications: Thousand Oaks, CA, USA, 2009; Volume 5. [CrossRef]

55. Gerring, J. Case Study Research: Principles and Practice; Cambridge University Press: New York, NY, USA, 2007.

56. Bennett, A.; Checkel, J.T. Process Tracing: From Metaphor to Analytic Tool; Cambridge University Press: Cambridge, UK, 2015.

57. Dessler, D. Beyond Correlations: Toward a Causal Theory of War. Int. Stud. Q. 1991, 35, 337-355. [CrossRef]

58. Fabbri, C.; Labartino, N.; Manfredi, S.; Piccinini, S. Biogas, il settore è strutturato e continua a crescere. Suppl a L'Informatore Agrar. 2013, 11, 11-16. (In Italian)

59. Piccinini, F.; Bonazzi, S.; Fabbri, G.; Sassi, C.; Schiff, D.; Soldano, M.C.; Verzellesi, M. Energia dal Biogas. Prodotto da Effluenti Zootecnici, Biomasse Dedicate e di Scarto; Centro Ricerca Produzioni Animali, CRPA: Padova, Italy, 2008. (In Italian)

60. Cattafi, M.; Gavanelli, M.; Milano, M.; Cagnoli, P. Sustainable biomass power plant location in the Italian Emilia-Romagna region. ACM Trans. Intell. Syst. Technol. 2011, 2, 1-19. [CrossRef]

61. Cooke, P. Building a twenty-first century regional economy in Emilia-Romagna. Eur. Plan. Stud. 1996, 4, 53-61. [CrossRef]

62. Mazzanti, M.; Pini, P.; Tortia, E. Organizational innovations, human resources and firm performance: The Emilia-Romagna food sector. J. Soc. Econ. 2006, 35, 123-141. (In Italian) [CrossRef]

63. López-estornell, M.; Barberá-tomás, D.; García-reche, A.; Mas-verdú, F. Evolution of innovation policy in Emilia-Romagna and Valencia: Similar reality, similar results? Eur. Plan. Stud. 2014, 22, 2287-2304. [CrossRef]

64. Servizio Statistica ER. Dimensione Economica e Specializzazione delle Aziende Agricole in Emilia-Romagna Nel 2010. $6^{\circ}$ Censimento Generale Dell'agricoltura; Regione Emilia-Romagna: Bologna, Italy, 2014. (In Italian)

65. ARPA-Emilia Romagna-CTR Energia e Valutazioni Ambientali Complesse, Centrali Energetiche a Biomasse 2015—Google Fusion Tables 2016. Available online: https:/ / fusiontables.google.com/DataSource? docid=11WLPSgNkbLATOha_CMDhNOWEzRGfml-RitPqWbP0\#rows:id=1 (accessed on 27 Feburary 2017). (In Italian)

66. Estensione Delle reti di Distribuzione e Loro Proprietà. Available online: http://www.autorita.energia.it/it/ dati/gm54.htm (accessed on 27 Feburary 2017). (In Italian)

67. Contributo dei Principali Operatori alla Produzione Nazionale Lorda. Available online: http://www. autorita.energia.it/it/dati/eem30.htm (accessed on 27 Feburary 2017). (In Italian)

68. Primi Venti Gruppi Nella Distribuzione. Available online: http://www.autorita.energia.it/it/dati/gm55. htm (accessed on 27 Feburary 2017). (In Italian)

69. Contributo dei Maggiori Gruppi Alla Generazione Rinnovabile per Fonte. Available online: http:/ /www. autorita.energia.it/it/dati/eem97.htm (accessed on 27 Feburary 2017). (In Italian)

70. Gas Naturale Distribuito per Regione. Available online: http://www.autorita.energia.it/it/dati/gm34.htm (accessed on 27 Feburary 2017). (In Italian)

71. Produzione Lorda di Energia Elettrica per Fonte. Available online: http://www.autorita.energia.it/it/dati/ eem6.htm (accessed on 27 Feburary 2017). (In Italian)

72. Bilancio del Gas Naturale. Available online: http://www.autorita.energia.it/it/dati/gs1.htm (accessed on 27 Feburary 2017). (In Italian)

73. Primi Venti Importatori in Italia. Available online: http://www.autorita.energia.it/it/dati/gm51.htm (accessed on 27 Feburary 2017). (In Italian)

74. Cavicchi, B. The Burden of Sustainability: Obstacles to sustainable bioheat development in Norway. In Proceedings of the 34th International Conference of the System Dynamics Society, Delft, The Netherlands, 17-21 July 2016.

75. Adams, P.W.; Hammond, G.P.; McManus, M.C.; Mezzullo, W.G. Barriers to and drivers for UK bioenergy development. Renew. Sustain. Energy Rev. 2011, 15, 1217-1227. [CrossRef] 
76. Taylor, P.; Bolkesj, T.F.; Tr, E.; Solberg, B. Bioenergy from the forest sector: Economic potential and interactions with timber and forest products markets in Norway. Scand. J. For. Res. 2006, 21, 175-185.

77. McCormick, K.; Kåberger, T. Exploring a pioneering bioenergy system: The case of Enköping in Sweden. J. Clean. Prod. 2005, 13, 1003-1014. [CrossRef]

78. Dale, V.H.; Kline, K.L.; Wright, L.L.; Perlack, R.D.; Downing, M.; Graham, R.L. Interactions among bioenergy feedstock choices, landscape dynamics, and land use. Ecol. Appl. 2011, 21, 1039-1054. [CrossRef] [PubMed]

79. Bluemling, B.; Mol, A.P.J.; Tu, Q. The social organization of agricultural biogas production and use. Energy Policy 2013, 63, 10-17. [CrossRef]

80. Thornley, P.; Upham, P.; Tomei, J. Sustainability constraints on UK bioenergy development. Energy Policy 2009, 37, 5623-5635. [CrossRef]

81. Mårtensson, K.; Westerberg, K. How to transform local energy systems towards bioenergy? Three strategy models for transformation. Energy Policy 2007, 35, 6095-6105. [CrossRef]

82. Shenton, A.K. Strategies for ensuring trustworthiness in qualitative research projects. Educ. Inf. 2004, 22, 63-75. [CrossRef]

83. Patton, M.Q. Qualitative Evaluation and Research Methods; Sage Publications: Newbury, CA, USA, 1990.

84. Patton, M.Q.; Cochran, M. A Guide to Using Qualitative Research Methodology. Available online: https://d1pbog36rugm0t.cloudfront.net/-/media/science/research-and-teaching/teaching/qualitativeresearch-methodology.pdf (accessed on 27 Feburary 2017).

85. STAT. Principali Dimensioni Geostatistiche e Grado di Urbanizzazione del Paese. Available online: http:/ / www.istat.it/it/archivio/137001 (accessed on 27 Feburary 2017). (In Italian)

86. Dijkstra, L.; Poelman, H. A Harmonised Definition of Cities and Rural Areas: The New Degree of Urbanisation. Available online: http://ec.europa.eu/regional_policy/sources/docgener/work/2014_01_ new_urban.pdf (accessed on 27 Feburary 2017).

87. Emilia-Romagna, R. Piano Forestale Regionale 2007-2013. Available online: http:/ /www.provincia.rm.it/ dipartimentoV/SitoGeologico/editore/documentiUpload/CARBONE_PRESENTAZIONE\%2018_12_09. PDF (accessed on 27 Feburary 2017).

88. La Legge Costituzionale 18 Ottobre 2001, n.3. Available online: http://www.parlamento.it/parlam/leggi/ 010031c.htm (accessed on 27 Feburary 2017). (In Italian)

89. Piazza della Repubblica. Attuazione Della Direttiva 2001/77/CE Relativa Alla Promozione Dell'energia Elettrica Prodotta Da Fonti Energetiche Rinnovabili Nel Mercato Interno Dell'elettricità; Gazzetta Ufficiale: Rome, Italy, 2004; Volume 24. (In Italian)

90. Piazza della Repubblica. Attuazione Della Direttiva 2009/28/CE Sulla Promozione Dell 'Uso Dell' Energia Da Fonti Rinnovabili, Recante Modifica E Successiva Abrogazione Delle Direttive TITOLO I FINALITA' E OBIETTIVI; Gazzetta Ufficiale: Rome, Italy, 2011; Volume 81. (In Italian)

91. Ministry for Economic Development. Italian National Renewable Energy Action Plan; Ministry of Economic Develoment: Rome, Italy, 2010; pp. 1-230.

92. Ministero dello Sviluppo Economico. Linee Guida per L'autorizzazione Degli Impianti Alimentati Da Fonti Rinnovabili, Decreto 10 Settembre 2010; Ministero dello Sviluppo Economico: Roma, Italy, 2010. (In Italian)

93. Ministero dello Sviluppo Economico. Incentivazione Della Produzione di Energia Elettrica da Fonti Rinnovabili, ai Sensi Dell'articolo 2, Comma 150, Della Legge 24 Dicembre 2007, N. 244. 2008. Available online: http:/ / www.camera.it/temiap/temi16/dm2008--12--18.pdf (accessed on 1 March 2016). (In Italian)

94. European Parliament and the Council. Directive 2009/28/EC on the promotion of the use of energy from renewable sources and amending and subsequently repealing Directives 2001/77/EC and 2003/30/EC. Off. J. Eur. Union 2009, 140, 16-62.

95. Gestore Servizi Energetici. GSE-All-Inclusive Feed-in Tariff. Available online: http://www.gse.it/en/ qualificationandcertificates/Theall-inclusivefeed-intariff/Pages/default.aspx (accessed on 27 Feburary 2017).

96. Gestore Servizi Energetici. GSE-Green Certificates (GCs). Available online: http://www.gse.it/en/ qualificationandcertificates/GreenCertificates/Pages/default.aspx (accessed on 27 Feburary 2017).

97. Governo della Repubblica. Disposizioni per la formazione del bilancio annuale e pluriennale dello Stato (legge finanziaria 2008). Am. Hist. Rev. 2008. (In Italian) [CrossRef]

98. Centro Ricerca Produzione Animali-(CRPA), FAQ—Sportello Olio. Available online: http://www.crpa.it/ nqcontent.cfm?a_id=7233\& (accessed on 27 Feburary 2017). (In Italian) 
99. Gestore Servizi Energetici. Guida Agli Incentivi per la Produzione di Energia Elettrica da Fonti Rinnovabili; Gestore Servizi Energetici: Roma, Italy, 2010. (In Italian)

100. Gestore Servizi Energetici. Incentives as per MD of 6 Jul. 2012. Available online: http://www.gse. it/en/qualificationandcertificates/Incentives\%20Ministerial\%20Decree/Pages/default.aspx (accessed on 27 Feburary 2017). (In Italian)

101. US Chamber of Commerce. Assessing Risk in A Global Energy Market International Index of Energy Security Risk. Assessing Risk in a Global Energy Market. 2015. Available online: http:/ /www.energyxxi.org (accessed on 27 Feburary 2017).

102. Brasili, C. La Storia Recente Degli Zuccherifici in Italia-Il Sistema Agro-Alimentare dell'Emilia Romagna; University of Bologna: Bologna, Italy, 2005; pp. 1-20. (In Iitalian)

103. Valle, S. La Riforma dell' OCM Zucchero nell' UE e Una Valutazione del Suo Impatto per i Produttori Bieticoli di Veneto ed Emilia Romagna; Università degli Studi della Tuscia: Lazio, Italy, 2007. (In Italian)

104. Girelli, E.; Ragazzi, M.; Malloci, E.; Cristina, E. Agricultural biomass availability for energy conversion in Italy. Sci. Bull. Ser. C 2012, 74, 11-18.

105. Regionale, C. Disciplina Della Programmazione Energetica Territoriale Ed Altre Disposizione in Materia Di Energia; Bollettino Ufficial della Regione Emilia Romagna: Bologna, Italy, 2004. (In Iitalian)

106. Assessorato Attività Produttive e Sviluppo Economico. Piano Energetico Regionale; Assessorato Attività Produttive e Sviluppo Economico: Bologna, Italy, 2007; pp. 1-225. (In Italian)

107. European Council. Regulation 1698/2005-EAFRD. Available online: http:/ / eur-lex.europa.eu/LexUriServ / LexUriServ.do?uri=OJ:L:2005:277:0001:0040:EN:PDF (accessed on 27 Feburary 2017).

108. Unione dei Comitati per l'Ambiente. Richiesta di Moratoria delle Autorizzazioni Alla Costruzione Nella Regione Emilia Romagna di Centrali a Biomasse o Biogas; Unione dei Comitati per l'Ambiente: Bologna, Italy, 2011. (In Italian)

109. del Mercato Fondiario in Italia nel 2013: Sintesi dei Risultati. Available online: http:/ /dspace.crea.gov.it/ bitstream/inea/1054/1/Andamento_merc_fond_It_2013.pdf (accessed on 27 Feburary 2017). (In Italian)

110. Mercato Fondiario e Affitti, L'analisi di Inea-AgroNotizie-Economia e Politica. Available online: http:/ / agronotizie.imagelinenetwork.com/agricoltura-economia-politica/2011/07/21/mercatofondiario-e-affitti-l-analisi-di-inea/13735 (accessed on 27 Feburary 2017). (In Italian)

111. Regione Emilia Romagna-Territorio. Valori Agricoli Medi 2015-Osservatorio Contratti Pubblici-E-R Territorio. Available online: http://territorio.regione.emilia-romagna.it/osservatorio/notizie/valoriagricoli-medi-2015 (accessed on 27 Feburary 2017). (In Italian)

112. Con i Piedi per Terra. INEA, la Crisi Pesa Sul Mercato Fondiario. Meglio Gli Affitti-Con i Piedi per Terra. Available online: http:/ / www.conipiediperterra.com/inea-la-crisi-pesa-sul-mercato-fondiario-meglio-gliaffitti-0725.html (accessed on 27 Feburary 2017). (In Italian)

113. Romagna, A.L.E. Individuazione Delle Aree e Dei Siti per L'installazione di Impianti di Produzione di Energia Elettrica Mediante L'utilizzo Delle Fonti Energetiche Rinnovabili Eolica, da Biogas, da Biomasse e Idroelettrica; Proposta della Giunta Regionale in Data 4 Lugl; Regione Emilia Romagna: Bologna, Italy, 2011; pp. 1-28. (In Italian)

114. Giunta Regionale. Criteri Tecnici Per La Mitigazione Degli Impatti Ambientali Nella Progettazione E Gestione Degli Impianti A Biogas; Regione Emilia Romagna: Bologna, Italy, 2011; pp. 1-36. (In Italian)

115. Centro Innovazione Sostenibilità Ambientale-CISA. Impianti e Progetti Realizzati. Available online: https:/ / www.centrocisa.it/progetti/impianti-e-progetti-realizzati.html (accessed on 27 Feburary 2017). (In Italian)

116. Monterenzio C di. Approvazione del Percorso Participato Finalizzato All'approvazione del Regolamento per il Risparmio Energetico e L'uso Delle Fonti Rinnovabili Nelle Attivita' Produttive. Processo Partecipato ai Sensi Della lr3/10. 2015. Available online: file:///Users/biancacavicchi/Downloads/MONTERENZIO.pdf (accessed on 2 March 2016). (In Italian)

(C) 2017 by the authors. Licensee MDPI, Basel, Switzerland. This article is an open access article distributed under the terms and conditions of the Creative Commons Attribution (CC BY) license (http:/ / creativecommons.org/licenses/by/4.0/). 